\title{
Miksi John Dewey on erityisen tärkeä juuri nyt?
}

Kai Alhanen (2013). John Deweyn kokemusfilosofia.

Helsinki: Gaudeamus. 278 s. ISBN: 978-952-495-283-5

KUN I990-LUVUN alussa kiinnostuin ensimmäisen kerran John Deweyn (1859-1952) tuotannosta, suorastaan hämmennyin hänen mittavan, yli 40 vuoden aikana kertyneen tuotannon ja aktiivisen elämäntyön äärellä. Ymmärsin jo silloin Deweyn merkityksen aikuiskasvatuksen, yhteiskunnallisen ja kulttuurisen muutoksen, henkisen kasvun, sivistyksen ja kehityksen tutkimuksessa. Haaviini tarttui erityisesti Deweyn kokemusfilosofian idea kokemuksellisen jatkumon rakentamisen tärkeydestä.

Yksilö voi elämässään vastustaa elämänkokemuksensa hajaantumista, elämän pinnallistumista ja elämänotteen pirstoutumista rakentamalla kaikesta tekemisistään ja pyrkimyksistään kokemuksellisen jatkumon. Jatkumossa menneisyys elää nykyisyydessä ja tulevaisuudessa, mikä voi johtaa kriittisen reflektion ja dialektisen ajattelun kautta kehittyvään ymmärrykseen jo koetusta.

Kesti kuitenkin lähes parikymmentä vuotta ennen kuin palasin uudestaan Deweyn ajatteluun Kai Alhasen teoksen innostamana. Deweyn merkitykseen tutkimuksessa on viime vuosina viitattu aiemminkin, esimerkiksi Osmo Kivinen ja Pekka Ristelä kirjassa Totuus, kieli ja käytäntö (2001), jossa suhde Deweyn ajatteluun jää kuitenkin kovin pinnalliseksi ja hajanaiseksi.

\section{AJANKOHTAINEN ELÄMÄNKULUN TUTKIJA}

Kai Alhasen kirjoittama teos toimii hyvänä ja sivistävänä johdantona Deweyn laajaan tuotantoon. Dewey yhdistetään usein pelkästään lasten ja nuorten toiminnalliseen oppimiseen ja progressiivisiin koulukokeiluihin. Hänen filosofiansa ja elämäntyönsä avaa kuitenkin laajan näköalan koko elämänkulun kysymyksiin aina henkisestä kasvusta ja kehityksestä yhteiskunnalliseen ja kulttuuriseen demokratisointiin ja luontosuhteeseen. Dewey kuuluu niihin merkittäviin tutkijoihin ja vaikuttajiin, joilta löytyy edelleen painavaa sanottavaa nykykulttuurista, joka pirstoo arjen ymmärrystä ja kokemusta monin tavoin. Dewey on monessa suhteessa hämmästyttävällä tavalla moderni ajattelija ja edellä omaa aikaansa. Dewey on klassikko, joka laajentaa toimintateoreettista lähestymistapaa myös aikuisuuden kas- vun, uusiutumisen ja kehityksen kysymyksiin.

Deweyn vaikutus inhimillisen toiminnan analysoinnin ja kokemusfilosofian edustajana on tunnistettavissa monin tavoin alan tutkimuksessa, vaikka Deweyn teksteihin ei suoraan viitattaisikaan. Kokemuksen käsite korostuu kaikessa aikuiskasvatuksellisessa teoretisoinnissa (esim. Lindeman 1926 tai Usher 1992). Deweyn vaikutus on näkynyt laajasti myös käytännön kehittämistyössä. Kehittämisen kohteen mallintaminen on usein edennyt kokemuksellisen oppimisen syklien tai kehittävän työntutkimuksen kolmiotyökalujen avulla. Silti on hämmästyttävää, että Deweyn kokemusfilosofiaan viitataan niin vähän. Esimerkiksi Kivinen ja Ristelä $(2001,146)$ väittävät, että jopa Pierre Bourdieun habituskäsite on kuin suoraa lainaa Deweyltä. Toimintatutkimuksessa ja aikuiskasvatustutkimuksessa Reijo Miettinen (1989, myös esim. 2000) on lähes ainut suomalainen tutkija, joka on toistuvasti useissa artikkeleissaan palannut Deweyn toiminnan teoriaan ja kokemuksellisen oppimisen ideoihin. 
Vaikka Deweyn keskeiset filosofiset, teoreettiset ja käytännölliset ideat elämänkokemuksen sekä toiminnan ja oppimisen välisen elävän suhteen merkityksestä ovat olleet laajasti käytössä, tuntevat harvat Deweyn filosofista kokonaisajattelua ja sen suhdetta esimerkiksi ekologiseen ajatteluun. Samoin Deweyn demokraattiseen yhteisöelämään, taiteen merkitykseen ja uskontoelämään liittyvät teoriat ovat jääneet aikuiskasvatuksessa hyödyntämättä. Yhteiskunnassa ja kulttuurissa, jossa kohdataan juuri nyt syvän taloudellisen taantuman mukanaan tuoma epävarmuus sekä kokemuksen pirstoutumisen, hajaantumisen ja elämän mielekkyyden, ja myös elämän mielen, katoamisen ongelmia, Dewey on monella tapaa juuri nyt ajankohtainen tutkija ja ajattelija.

\section{KOKEMUSFILOSOFIA PURKAA VASTAKKAISUUKSIA}

Alhasen teoksessa minuun vetosi pyrkimys pelastaa Deweyn kokemuksen käsite ja rakentaa kokonaiskuvaa Deweyn filosofisesta ajattelusta suhteessa nykyaikaan, jossa aktualisoituvat uudenlaiset sosiaaliset, kulttuurisesti polttavat ja ajankohtaiset ongelmat. Kuten Alhanen toteaa, tunnetaan Dewey Suomessa ja maailmalla lähinnä vain oppimista ja kasvatusta koskevista näkemyksistään ja teorioistaan. Tällainen näkökulmien rajoittuneisuus johtaa Deweyn puutteelliseen ja usein vääränlaiseen ymmärtämiseen. Deweyn mittavan tutkijantyön yhdistäminen pelkästään iskulauseisiin "tekemällä oppiminen" (learning by doing) tai "edistyksellinen kasvatus" (progressive education) sivuuttaa hänen laaja-alaisen filosofin elämäntyönsä, joka liittyy oppimisen ydinprosessien lisäksi myös huomattavasti laajempaan maailmanselitykseen. Mikään inhimillisesti tärkeä ei näytä olevan Deweyn filosofin silmälle vierasta.

Dewey halusi uudistaa länsimaisen filosofian uudella kokemusfilosofiallaan, joka ylitti totuttuja dualiteetteja monin tavoin. Hänen laaja tuotantonsa purkaa perustavaa laatua olevia vastakkaisuuksia teorian ja käytännön, faktojen ja arvojen, subjektin ja objektin, mielen ja ruumiin, aistimusten ja ideoiden, kulttuurin ja luonnon, tieteen ja taiteen, kokeellisen tutkimuksen ja kulttuurisesti jaettujen merkitysten välillä. Kahtiajakoja purkamalla Dewey tarjoaa edelleen äärimmäisen ajankohtaisen näkemyksen myös filosofian perimmäisestä tehtävästä.

\section{EKOLOGISEN AJATTELUN EDELLÄKÄVIJÄ}

Alhasen mukaan Dewey rakentaa kokemusfilosofiallaan myös eko- logista maailmankuvaa. Deweyn kokonaisvaltaisen kokemusfilosofian ytimenä on demokratian ideaali. Alhanen tulkitsee Deweyn rakentavan kaikkien elollisten olentojen kokemukselliseen oppimiseen perustuvalla yhteiselämän ihanteellaan suorastaan eräänlaista "ekokratiaa", jonka ehtoja Alhanen toivoo tämän päivän tutkijoiden pohdiskelevan tosissaan.

Alhanen nimeää Deweyn ekologisen kokemuskäsityksen edustajaksi. C.W. Tolman ja B. Piekkola (1989) nimesivät Deweyn evolutionaristiseksi naturalistiksi ja pohtivat hänen turbulenttia suhdettaan erityisesti dialektiseen materialismiin ja Leontjevin edustamaan kulttuurihistorialliseen toiminnan teoriaan. Heidän mukaansa Dewey voidaan ihan oikeutetusti lukea myös materialisteihin. Epäilen itse, että Dewey kaikenlaisten dualismien purkajana tuskin olisi itse ollut samaa mieltä tästä tulkinnasta.

Kai Alhanen ehdottaa Deweyä ekokratian edistäjäksi, koska Dewey pohtii laajasti ihmisen asemaa ja roolia elollisten olentojen joukossa ilman kahtiajakoja esimerkiksi luontoon ja ihmiselämään. Alhanen nimeää Deweyn kokemusfilosofian ja tutkijantyön päätavoitteeksi demokratian ja demokraattisen yhteisöelämän edistämisen. Demokraattisen yh- 
teisöelämän tulee Deweyn mukaan pyrkiä siihen, että kaikkien elollisten olentojen kokemuksista oppiminen on mahdollista. Näin on mahdollista tavoitella myös yhdessä toimien harmoniaa koko yhteiskunnan luontosuhteen hyväksi. Dewey oli lukenut hyvin Darwininsa. Hänen kokonaisvaltainen maailmanselityksensä ulottui luontosuhteesta myös ihmisten laajasti jakamiin uskonnollisiin kokemuksiin ja erityisesti taiteen ja esteettisten kokemuksen rooliin ihmisen jalostajana ja erilaisten yllykkeiden mahdollistajina.

\section{TAITEEN JA ESTEETTISEN KOKEMUKSEN MERKITYS}

Erityisen kiinnostavaa Deweyn kokemuksellisen jatkumon ideassa on taiteen ja esteettisen kokemuksen merkitys ihmisen elämässä. Esteettiset kokemukset ovat hetkiä, jolloin kokemusjatkumolla haetaan uudenlaista suhdetta koettuun. Tällöin yksilö voi kokea kokemuksen eheyden jopa niin, että kokemuksen tapa muuttaa muotoaan. Esteettinen kokemus voi toimia yllykkeenä, joka muuttaa yksilön ja hänen ympäristönsä suhdetta herkkävireisellä tavalla uuteen muottiin. Yksilö ryhtyy havainnoimaan kokemustaan uudella tavalla. Yksilön muistot saavat mielikuvituksen avulla uusia merkityksiä ja yksilö muokkaa kokemustaan uudenlaisesta näkökulmasta.

Dewey siis antaa taiteelle aivan erityisen roolin tekijänä, joka auttaa yksilöä oppimaan kokemuksista ja laajentamaan kokemustaan. Taide ikään kuin auttaa vetämään verhot kokemustemme edestä ja elvyttää "meidät tottumuksiemme velttoudesta ja sallii meidän unohtaa itsemme antaessaan meidän ilahtua siitä, että voimme kokea maailman monenlaisine ominaisuuksineen ja muotoineen" (Dewey; ks. Alhanen 2013, 190).

\section{MORAALI AIKANSA TUOTTEENA}

Dewey johdattaa meidät myös kysymään moraalisia kysymyksiä. Hän ei näe moraalia muuttumattomana ja pysyvänä, vaan korostaa, että kukin aika tuottaa oman moraalinsa. Siksi on tärkeä kysyä, millaiseksi ihmisiksi haluamme kunakin aikana kehittyä, millaiseksi minuutemme on tässä ajassa muuttumassa, ja millaista maailmaa me haluamme teoillamme rakentaa. Tässä harkinnassa meillä on apuna muistimme, kykymme, aistimme, pyyteemme ja halumme, joita meidän on hyvä ja tärkeää jalostaa erilaisilla yllykkeillä.

Koulutus ja kasvatus voivat olla yllykkeitä, jotka herättävät ajattelua ja kehittävät tietoisuutta tekojemme ja halujemme seurauksista. Näin ymmärrämme paremmin tekojemme merkityksen. Pohdinnan kautta on mahdollisuus rakentaa uudenlaisia moraalisubjekteja, jotka pystyvät irrallisen ja pirstaleisen tietämisen ja osaamisen sijasta rakentamaan kokemuksellista jatkumoa, joka kantaa yli konkreettisten tilanteiden. Tällaiset pohdinnan ja harkinnan hetket ovat epäröinnin hetkiä, jolloin korjaamme elämäämme ohjaavia perustavia merkityksiä ja ohjaudumme tutkimaan toimintamme kohdetta tarkemmin kokeellisesti.

Tiede on välttämätöntä kokeellista toimintaa, jonka avulla voimme rakentaa ja korjata omaa kokemusjatkumoamme. Tiede on sosiaalista toimintaa, jota Deweyn mukaan ei tule opettaa irrallaan sen kulttuurisista yhteyksistä tai vaikutuksista ihmiskunnan yhteisille ponnistuksille. Ainutlaatuisen tilanteen tutkiminen on haaste, jonka avulla kokeellisesti tutkimme toimintamme kohdetta ja tarkennamme ja muutamme tarvittaessa ymmärrystämme.

\section{"OSAAJIEN" SIJAAN TULEE KEHITTÄÄ "KYSYJIÄ"}

Tässä "osaajien” ja "osaamislähtöisten opetussuunnitelmien" yritysyliopistoajassa on tärkeää huomata Deweyn ajatus siitä, että "valmiin muotin", eli valmiiden tietojen ja taitojen, opettaminen ei ole järkevää jatkuvasti muut- 
tuvassa maailmassa. Tämänhetkiseen kokemukseen liittyvien merkitysten työstäminen edistää opiskelijan kykyä ja halua jatkuvaan kasvuun. Se luo edellytyksiä muokata kokemusta myös myöhemmin. Deweyn ajatus on parantaa kokemuksellisen jatkumon edellytyksiä niin, että kokemuksen rikastaminen, uudistaminen ja uudelleenjäsentäminen kaikissa elämänvaiheissa on mahdollista.

Tärkeää on myös huomioida Deweyn ajatus siitä, miten synnytetään yksilölle tärkeitä tottumuksia ja rutiineja, ja miten luodaan kokemuksellisten jatkumoiden joustavuutta ja kykyä uudelleenorientoitumiseen. Parhaiten se tapahtuu oppimistilanteissa, joissa on paljon muuntelua, kokeiluja sekä eri toimintojen ja oman toiminnan yhdistämistä. Taitojen sijasta kysymys lienee ennemminkin yleissivistävästä otteesta ja laaja-alaisesta tutkivasta otteesta, joka on ominaista perinteiselle yliopisto-opiskelulle. Tärkeää on auttaa yksilöä miettimään erilaisia vaihtoehtoisia tapoja ymmärtää tutkimuksen kohdetta ja sen kehityksen ehtoja. Osaajien sijasta onkin syytä tukea ja kehittää "kysyjiä", jotka kykenevät kyseenalaistamaan annettua.

\section{KOKEMUSTEN JAKAMISEN TÄRKEYDESTÄ}

Elämäntyössään John Dewey selvitti tutkijana, filosofina ja yhteiskunnallisena vaikuttajana kokemusfilosofiansa suhdetta länsimaisen filosofian perinteisiin. Välienselvittelyn jälkeen Dewey tarjosi uudenlaisen näkemyksen ihmiskokemuksesta ja kokemuksen kehittymisestä yhteistoiminnassa. Miten edetään tottumuksista yllykkeiden, heränneiden halujen, uudenlaisten kokeilujen, muistamisen, mielikuvituksen ja älyllisten pohdintojen kokemuksen ja toiminnan jatkumolle, jossa menneisyys muokkaa, heijastuu nykyisyyteen ja vaikuttaa myös tulevaisuuteen? Deweyn kokemusfilosofia rakentaa ikään kuin sisäisen katseen kautta ymmärrystä toimintaan, joka etenee kokemusten jakamisesta ehdotelmiin ja kokemusten testaamiseen. Siinä totuttuun yhdistetään uusia ajatuksia ja hypoteeseja tilanteissa, joissa yksilö rakentaa merkitysverkostojaan ja toiminnan mielekkyyttä.

Pohdintojen jakaminen kommunikoimalla auttaa kirkastamaan, monipuolistamaan ja korjaamaan pohdintojen ytimen. Yksilön kokemusta on muotoiltava ja tarkasteltava ulkopuolelta, että näkee ja ymmärtää kokemuksen merkityksen. Merkitysten ja kokemusten ymmärtämisen risteyspiste on inhimillisessä vuorovaikutuksessa kommunikaatio. Tämä ei kuiten- kaan erota Deweyn mukaan ihmistä ratkaisevalla tavalla muusta luonnosta. Merkitykset voivat kehittyä tietoisen työstämisen ja yhteisöllisen kommunikaation ansiosta, mutta rajoittavassa ja auktoriteettien ohjauksessa ihmiskokemus voi myös kaventua ja pirstoutua. Uudenlaisissa tilanteissa tarvitaan herkkyyttä ja joustavuutta, joka edistää kokemuksista oppimista. Tällaisia kokemuksellisia jatkumoita voidaan rakentaa olosuhteissa, joissa sallitaan runsaasti kokeiluja ja rohkaistaan uudenlaisten asioiden yhdistelyä ja toiminnan älyllistä pohtimista.

Jälkikäteen on vaikea ymmärtää, miten on mahdollista, että John Dewey pitkän tieteellisen uransa aikana ehti myös vaikuttaa hyvin monipuolisesti erityisesti oman yhteiskuntansa murroksiin ja edistyksellisiin pyrkimyksiin. Deweyn filosofian tehtävänä on auttaa irrallisten olemuspohdintojen sijasta ymmärtämään paremmin sitä maailmaa ja niitä olosuhteita, joiden keskellä ihmiskunta elää ja pyrkii vaikuttamaan omaan nykyisyyteensä ja tulevaisuuteensa.

Aikuiskasvattajille Deweyn elämäntyö on erityisen tärkeä ja Kai Alhasen teos toimii hyvänä johdattajana Deweyn ajatteluun. Perehtymistä voi jatkaa Deweyn omilla teksteillä nyt 
myös suomen kielellä. Deweyltä on aiemmin suomennettu vain yleistajuisiin luentoihin perustuva kirja Koulu ja yhteiskunta (1907/1957). Tamperelaisten filosofian harrastajien ja opiskelijoiden toimesta on sittemmin käännetty teokset Taide kokemuksena (2010) sekä Demokratia ja kasvatus (2015). Filosofisen aikakauslehden Niin \& Näin ylläpitäjät ovatkin tehneet merkittävän kulttuurityön Dewey-suomennoksillaan. Toivon, että kirjat löytävät tiensä mahdollisimman monen yliopiston kasvatustieteiden opinto- ja tutkimusvaatimuksiin oppikirjoiksi ja kuluvat aikuiskasvatuksen opiskelijoiden aktiivisessa käytössä.

Karin Filander

Esihenkilö, pj.

Aikuiskasvatuksen Tutkimusseura Tampereen yliopiston kasvatustieteiden yksikkö

\section{LÄHTEET}

Dewey, J. (1907/1957). Koulu ja yhteiskunta. Otavan filosofinen kirjasto 5. Helsinki: Otava.

Dewey, J. (1929/1999). Pyrkimys varmuuteen: Tutkimus tiedon ja toiminnan välisestä suhteesta. Helsinki: Gaudeamus.

Dewey. J. (2010). Taide kokemuksena. Tampere: Niin \& Näin- kirjat.

Dewey. J. (2015, tulossa). Demokratia ja kasvatus. Tampere: Niin \& Näin-kirjat.

Kivinen, O. \& Ristelä, P. ( 2001). Totuus, kieli ja käytäntö. Pragmatistisia näkökulmia toimintaan ja osaamiseen. Helsinki: WSOY.

Lindeman, E.C. (1926). The Meaning of Adult Education. New York: New Rebublic, Inc.

Miettinen, R. (1989). John Dewey's Concept of Activity and the Problem of School Curriculum. Comment on the Paper of Charles Tolman and Brad Piekkola. Discussion. Activity Theory 3/4 1989.

Miettinen, R. (2000). The concept of experiential learning and John Dewey's theory of reflective thought and action. International Journal of Lifelong Education 19(1).

Tolman, C. W. \& Piekkola, B. (1989). Anticipations of Activity Theory in the Critique of the Reflex Arc Concept. Activity Theory 3/4.

Usher R. (1992). Experience in Adult Education: a post-modern critique. Journal of Philosophy of Education 26(2), 201-214. 